\title{
Molecular identification of Amazonian stingless bees using polymerase chain reaction single-strand conformation polymorphism
}

\author{
M.T. Souza ${ }^{1}$ and G.A. Carvalho-Zilse ${ }^{2}$ \\ ${ }^{1}$ Programa de Pós-Graduação em Genética, \\ Conservação e Biologia Evolutiva, \\ Instituto Nacional de Pesquisas da Amazônia, Manaus, AM, Brasil \\ ${ }^{2}$ Grupo de Pesquisas em Abelhas, \\ Coordenação de Biodiversidade, \\ Instituto Nacional de Pesquisas da Amazônia, Manaus, AM, Brasil \\ Corresponding author: M.T. Souza \\ E-mail: trindadebiologa@gmail.com
}

Genet. Mol. Res. 13 (3): 5507-5513 (2014)

Received June 12, 2013

Accepted December 2, 2013

Published July 25, 2014

DOI http://dx.doi.org/10.4238/2014.July.25.4

\begin{abstract}
In countries containing a mega diversity of wildlife, such as Brazil, identifying and characterizing biological diversity is a continuous process for the scientific community, even in face of technological and scientific advances. This activity demands initiatives for the taxonomic identification of highly diverse groups, such as stingless bees, including molecular analysis strategies. This type of bee is distributed in all of the Brazilian states, with the highest species diversity being found in the State of Amazônia. However, the estimated number of species diverges among taxonomists. These bees are considered the main pollinators in the Amazon rainforest, in which they obtain food and shelter; however, their persistence is constantly threatened by deforestation pressure. Hence, it is important to classify the number and abundance of bee specie, to measure their decline and implement meaningful, priority conservation strategies. This study
\end{abstract}


aims to maximize the implementation of more direct, economic and successful techniques for the taxonomic identification of stingless bees. Specifically, the genes 16S rRNA and COI from mitochondrial DNA were used as molecular markers to differentiate 9 species of Amazonian stingless bees based on DNA polymorphism, using the polymerase chain reaction-single-strand conformation polymorphism technique. We registered different, exclusive SSCP haplotypes for both genes in all species analyzed. These results demonstrate that SSCP is a simple and cost-effective technique that is applicable to the molecular identification of stingless bee species.

Key words: Stingless bee; Amazônia; mtDNA; SSCP

\section{INTRODUCTION}

The identification of species belonging to megadiverse groups is a tremendous challenge for researchers, especially in Brazilian Amazônia, which is a region of continental dimensions. There are large gaps in the identification of Amazonian bees, because most collections are not systematic, do not satisfactorily cover species distribution areas, and are fragmented among zoological collections. Existing records indicate rich species diversity, emphasizing the need for the taxonomic revision of many groups, such as stingless bees in the tribe Meliponini (Roubik, 1989; Camargo and Pedro, 2003; Moure et al., 2007).

Meliponini are a remarkable tribe in the family Apidae, consisting of 33 genera and 397 species, as proposed by Moure et al. (2007). However, this estimate varies with authors, who recognize the difficulty of knowing the actual number of species, given the lack of taxonomic revision for this tribe and the large number of cryptic species (Michener, 2007). These bees are the most popular and well-known species of ecological and economic importance in Amazônia (Carvalho-Zilse and Nunes-Silva, 2012). Furthermore, with the documented decline of Apis bees worldwide, native bees are the main candidates for pollination and production programs (Slaa et al., 2006; Cruz and Campos, 2009).

Meliponini are distributed throughout the tropics $\left(35^{\circ} \mathrm{S}\right.$ on Australia and South America and $28^{\circ} \mathrm{S}$ on Africa; at North near $23,5^{\circ} \mathrm{N}$ ) (Michener, 2007). This tribe is found in all of the states in Brazil, with the greatest diversity being in the State of Amazônia (Nogueira-Neto, 1997). Silveira et al. (2002) proposed that 88 species exist in Amazônia, whereas Moure et al. (2007) proposed 115 species in this region. Without knowing how many bee species exist and how abundant they are, it is difficult to effectively exploit this group, to measure their decline, or to implement meaningful, priority conservation strategies (Brown and Paxton, 2009).

Traditional, morphology-based taxonomy has been considerably supported by the use of molecular markers, which have been proposed to be able to identify, characterize, and differentiate species. Hence, molecular tools are indispensable towards quantifying wildlife diversity, bringing important information to systematics and conservation (Hillis et al., 1996).

Here, we aimed to assimilate information for the detailed revision of the Meliponini tribe. Specifically, we tested the potential of the PCR-SSCP (polymerase chain reaction-single-strand conformation polymorphism) technique to develop a simple and rapid marker for 
the identification and molecular differentiation of Amazonian stingless bees using the COI (cytochrome oxidase I) and 16S rRNA (16S ribosomal RNA) regions of mitochondrial DNA. This technique has been extensively used, because it is sensitive to differences in DNA sequences, allowing the rapid processing of a large number of samples in the search for speciesspecific markers (Bastos et al., 2001; Lamarão et al., 2010).

\section{MATERIAL AND METHODS}

Adult individuals ( 5 individuals per colony) of 9 species of Amazonian stingless bees previously identified by a specialist were selected for this study; namely Melipona eburnea, Melipona seminigra, Melipona interrupta, Melipona nebulosa, Melipona rufiventris, Melipona dubia, Scaptotrigona polysticta, Scaptotrigona sp, and Trigona williana. These species were compared by PCR-SSCP, using the COI and 16S rRNA regions of mitochondrial DNA. Samples were collected from 10 municipalities (represented by numbers) in the Amazonas State; specifically: Autazes (8), Careiro Castanho (7), Iranduba (4), Manacapuru (5), Manaquiri (6), Manaus (2), Maués (10), Parintins (9), Rio Preto da Eva (3), and São Gabriel da Cachoeira (1) (Figure 1).

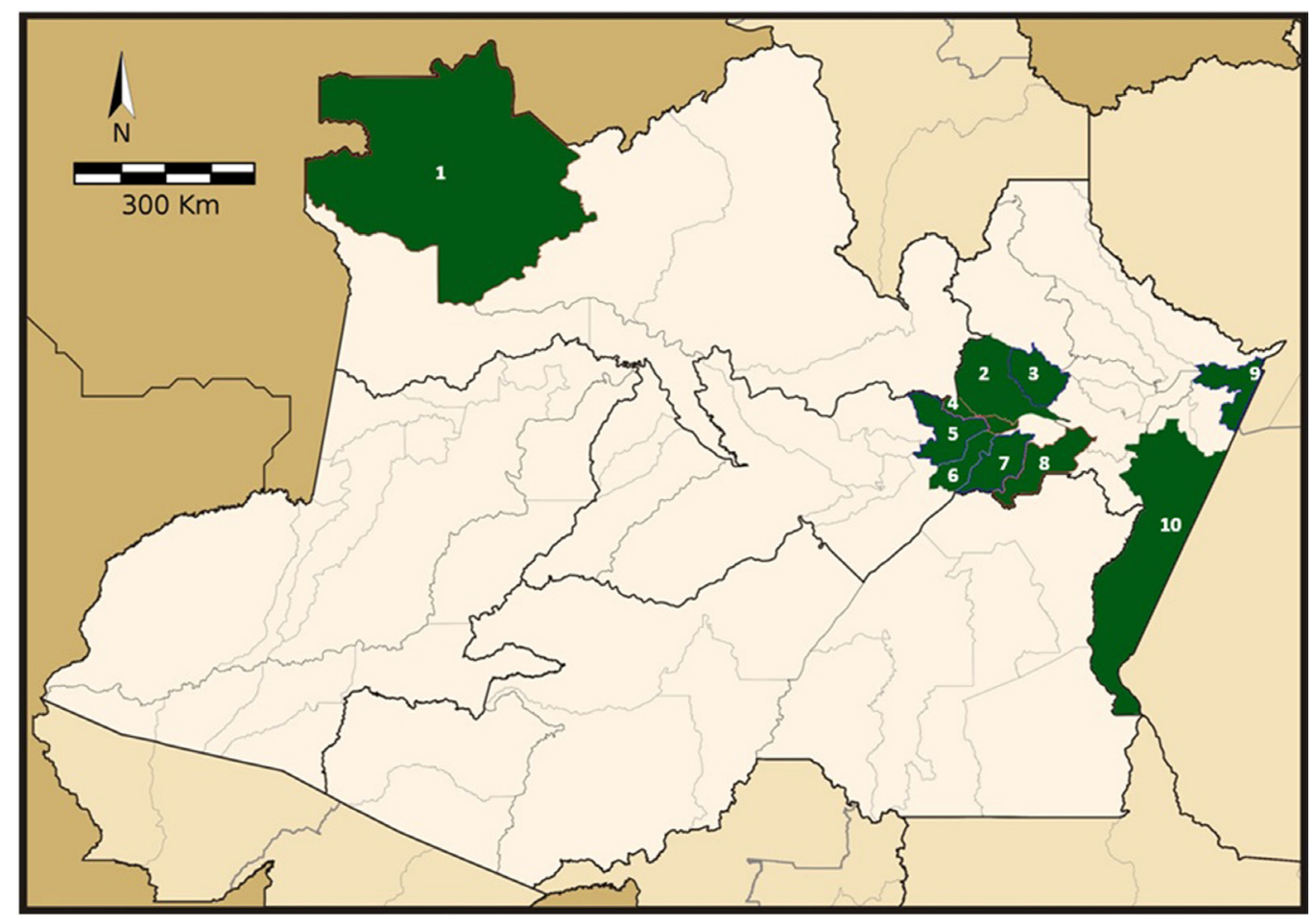

Figure 1. Municipalities of collection of stingless bee samples in the State of Amazonas, from left to right: $1=$ São Gabriel da Cachoeira; 2 = Manaus; 3 = Rio Preto da Eva; $4=$ Iranduba; $5=$ Manacapuru; $6=$ Manaquiri; 7 = Careiro Castanho; $8=$ Autazes; 9 = Parintins; $10=$ Maués. 
DNA was extracted from the thorax of each individual, following the protocol of Paxton et al. (1996). PCR was carried out in a Verity ${ }^{\mathrm{TM}}$ thermocycler (Applied Biosystems, USA) in a 20- $\mu$ L reaction mixture containing 25-75 ng DNA, $1 \mathrm{X}$ buffer, 1-3 $\mathrm{mM} \mathrm{MgCl}_{2}, 5-8$ pM primers; $200 \mathrm{mM}$ dNTPs, and 1-1.5 U Taq DNA polymerase (Promega Biotecnologia do Brasil). The PCR program was set to an initial cycle of $5 \mathrm{~min}$ at $94^{\circ} \mathrm{C} ; 35$ cycles of 2 min at $94^{\circ} \mathrm{C} ; 1 \mathrm{~min}$ at $51^{\circ} \mathrm{C}, 2 \mathrm{~min}$ at $70^{\circ} \mathrm{C}$, and $10 \mathrm{~min}$ at $70^{\circ} \mathrm{C}$ at the $16 \mathrm{~S}$ region, and $1 \mathrm{~min}$ at $94^{\circ} \mathrm{C}$; 5 cycles of $1 \mathrm{~min}$ at $94^{\circ} \mathrm{C} ; 1.5 \mathrm{~min}$ at $45^{\circ} \mathrm{C}$, and $1.5 \mathrm{~min}$ at $72^{\circ} \mathrm{C} ; 30$ cycles of $1 \mathrm{~min}$ at $94^{\circ} \mathrm{C}$, $1.5 \mathrm{~min}$ at $51^{\circ} \mathrm{C}$, and $1.5 \mathrm{~min}$ at $72^{\circ} \mathrm{C}$; and $5 \mathrm{~min}$ at $72^{\circ} \mathrm{C}$ for COI. The primers that were used were specific for M. compressipes (syn. M. interrupta) for the $16 \mathrm{~S}$ region (Bezerra, 1999), and from M. bicolor for the COI region (Simon et al., 1994).

For the SSCP technique, the amplified DNA was denatured for $5 \mathrm{~min}$ at $97^{\circ} \mathrm{C}$ in solution containing $2 \mu \mathrm{L}$ of the PCR product from each individual, plus $18 \mu \mathrm{L}$ buffer LIS-SSCP ( $10 \%$ saccharose, $0.01 \%$ bromophenol blue, $0.01 \%$ xylene cyanol). Then, electrophoresis on acrylamide gel (12\%) was carried out for $20 \mathrm{~h}$ and $30 \mathrm{~min}$ at $80 \mathrm{~V}$. Gels were stained with silver nitrate (Creste et al., 2001) and digitalized. The haplotype profile within and between species was compared with the aid of ImageJ version 1.42 (Rasband WS, ImageJ, USA National Institutes of Health, Bethesda, MD, USA, imagej.nih.gov/ij/, 1997-2012).

Genetic analyses were based on Nei's genetic distance (1978), using the TFPGA program (Tools for Population Genetic Analysis) version 1.3 (Miller, 1997).

\section{RESULTS AND DISCUSSION}

Of the 345 individuals from which DNA was extracted, 221 showed positive amplification for 16S (64.05\%) and 193 for COI (55.94\%), after the DNA was amplified for individuals of all species for both regions of the mitochondrial DNA. Vences et al. (2005) also analyzed both regions to obtain DNA barcodes for amphibians, and obtained $100 \%$ amplifications from samples for the $16 \mathrm{~S}$ region, while amplification of the COI region ranged from 50 to $70 \%$.

The PCR-SSCP of the $16 \mathrm{~S}$ region of all species produced 23 haplotypes (16SH1$16 \mathrm{SH} 23$ ), of which just 2 were shared. Specifically, $16 \mathrm{SH} 1$ was shared by $M$. interrupta and M. seminigra, while $16 \mathrm{SH} 5$ was shared by S. polysticta, M. interrupta, and M. eburnea. The COI region also had 23 haplotypes (COIH1-COIH23), of which 3 were shared. Specifically, 2 haplotypes (COIH10 and COIH11) were shared by M. eburnea and M. rufiventris, while COIH16 was shared by Scaptotrigona sp and S. polysticta.

In a study comparing bee species, Sheffield et al. (2009) found that most had unique sequences occurred in the COI region. In the current study, only M. dubia had unique haplotypes for both genes, while $T$. williana had a unique haplotype for COI. In the other species, the number of haplotypes ranged from 2 to 5 for $16 \mathrm{~S}$, and from 2 to 6 for COI. However, all 9 species contained exclusive haplotypes, allowing 100\% discrimination based on the PCR-SS$\mathrm{CP}$ of the COI and $16 \mathrm{~S}$ regions. This result supports the efficiency of this PCR-SSCP marker for both regions in the molecular identification of species from the tribe, and its potential for use as an interspecific molecular marker.

Based on interspecific haplotypic polymorphism, it was observed that the genetic distance among the studied species differed between the 2 genic regions. For 16S (Table 1), the genetic distance reached $100 \%$ among most species, which was expected, given the paucity of shared haplotypes. When haplotypes were shared, the distance was smaller. For instance, the 
difference was $80,70,70$, and 58\% between M. interrupta and M. seminigra, M. interrupta and M. eburnea, S. polysticta and M. eburnea, and M. interrupta and S. polysticta, respectively. The genetic distance found among species by PCR-SSCP for the COI region also reached 100\% when no haplotypes were shared. When haplotypes were shared, the distance was 1.4 and $58 \%$ between M. eburnea and M. rufiventris, and Scaptotrigona sp and S. polysticta (Table 2).

Table 1. Matrix of genetic distances (Nei, 1978) between the studied species based on the haplotype polymorphism of $16 \mathrm{~S}$ region.

\begin{tabular}{lcccccccc}
\hline Species & $\mathrm{Mi}$ & $\mathrm{Ms}$ & $\mathrm{Mr}$ & $\mathrm{Me}$ & $\mathrm{Mn}$ & $\mathrm{Md}$ & $\mathrm{Ssp}$ & $\mathrm{Sp}$ \\
\hline $\mathrm{Mi}$ & $* * * * *$ & & & & & & & \\
$\mathrm{Ms}$ & $\mathbf{0 . 8 0 4 7}$ & $* * * * *$ & & & & & \\
$\mathrm{Mr}$ & 1.0000 & 1.0000 & $* * * * *$ & & & & \\
$\mathrm{Me}$ & $\mathbf{0 . 7 0 7 2}$ & 1.0000 & 1.0000 & $* * * * *$ & & & \\
$\mathrm{Mn}$ & 1.0000 & 1.0000 & 1.0000 & 1.0000 & $* * * * *$ & & & \\
$\mathrm{Md}$ & 1.0000 & 1.0000 & 1.0000 & 1.0000 & 1.0000 & $* * * * *$ & & \\
$\mathrm{Ssp}$ & 1.0000 & 1.0000 & 1.0000 & 1.0000 & 1.0000 & 1.0000 & $* * * *$ & \\
$\mathrm{Sp}$ & $\mathbf{0 . 5 8 7 8}$ & 1.0000 & 1.0000 & $\mathbf{0 . 7 0 7 2}$ & 1.0000 & 1.0000 & 1.0000 & $* * * *$ \\
$\mathrm{Tw}$ & 1.0000 & 1.0000 & 1.0000 & 1.0000 & 1.0000 & 1.0000 & 1.0000 & 1.0000 \\
\hline
\end{tabular}

$\mathrm{Mi}=$ Melipona interrupta $; \mathrm{Ms}=M$. seminigra $; \mathrm{Mr}=$ M. rufiventris $; \mathrm{Me}=$ M. eburnea $; \mathrm{Mn}=M$. nebulosa $; \mathrm{Md}=$ M. dubia $; \mathrm{Ssp}=$ Scaptotrigona $\mathrm{sp} ; \mathrm{Sp}=$ S. polysticta $; \mathrm{Tw}=$ Trigona williana . Highlighted in bold for distances less than $100 \%$.

\begin{tabular}{|c|c|c|c|c|c|c|c|c|c|}
\hline Species & Mi & Ms & $\mathrm{Mr}$ & $\mathrm{Me}$ & $\mathrm{Mn}$ & $\mathrm{Md}$ & Ssp & $\mathrm{Sp}$ & Tw \\
\hline Mi & $* * * * *$ & & & & & & & & \\
\hline Ms & 1.0000 & $* * * * *$ & & & & & & & \\
\hline $\mathrm{Mr}$ & 1.0000 & 1.0000 & $* * * * *$ & & & & & & \\
\hline $\mathrm{Me}$ & 1.0000 & 1.0000 & 0.0141 & $* * * * *$ & & & & & \\
\hline $\mathrm{Mn}$ & 1.0000 & 1.0000 & 1.0000 & 1.0000 & $* * * * *$ & & & & \\
\hline $\mathrm{Md}$ & 1.0000 & 1.0000 & 1.0000 & 1.0000 & 1.0000 & $* * * * *$ & & & \\
\hline Ssp & 1.0000 & 1.0000 & 1.0000 & 1.0000 & 1.0000 & 1.0000 & $* * * * *$ & & \\
\hline $\mathrm{Sp}$ & 1.0000 & 1.0000 & 1.0000 & 1.0000 & 1.0000 & 1.0000 & 0.5878 & $* * * * *$ & \\
\hline $\mathrm{Tw}$ & 1.0000 & 1.0000 & 1.0000 & 1.0000 & 1.0000 & 1.0000 & 1.0000 & 1.0000 & $* * * * *$ \\
\hline
\end{tabular}

$\mathrm{Mi}=$ Melipona interrupta $; \mathrm{Ms}=M$. seminigra $; \mathrm{Mr}=$ M. rufiventris $; \mathrm{Me}=$ M. eburnea $; \mathrm{Mn}=$ M. nebulosa $; \mathrm{Md}=$ M. dubia $; \mathrm{Ssp}=$ Scaptotrigona $\mathrm{sp} ; \mathrm{Sp}=$ S. polysticta $; \mathrm{Tw}=$ Trigona williana. . Highlighted in bold for distances less than $100 \%$.

Sousa et al. (2003) showed that the PCR-SSCP marker was more adequate for the identification of mutations in M. rufiventris compared to DS-PCR (double-strand PCR) and PCR-RFLP (restriction fragment length polymorphism) of the 16S region. The current technique requires a smaller quantity of PCR-amplified DNA compared to other methods that are also based on PCR products. In addition, PCR-SSCP is accurate at detecting point mutations, which makes it attractive and effective both economically and performance-wise. Hence, lower reaction volumes and reagent concentrations of reactants may be used, thus decreasing the cost of the marker. Moreover, mutations are detected by the band migration profile, rather than by the absence of signal, as in other methods. Hence, failure during PCR does not lead to false-positive results (Hayashi, 1991).

Our study supports previous studies, in which the efficiency of this technique was 
demonstrated at distinguishing different species of microorganisms (Schwieger and Tebbe, 1998; MacGregor and Amann, 2006; Mohr and Tebbe, 2006), including sea sponges (Lamarão et al., 2010) and catfish (Sriphairoj et al., 2010), among others. In addition to identifying species, this technique has been indicated as a simple and accessible strategy for the validation of products processed from fish (Sriphairoj et al., 2010) and plants (Choa et al., 2011).

This study confirmed that both amplified regions (16S and COI) were efficient, producing values of genetic distance above $90 \%$. This value was confirmed through the evaluation of the average distances among all analyzed bee species $(96.61 \%$ for $16 \mathrm{~S}$ and $96.08 \%$ for COI), in addition to those found for species in the genus Melipona (96.74\% for 16S and 93.42\% for COI), in the group Trigona (genera Scaptotrigona and Trigona; $91.72 \%$ for $16 \mathrm{~S}$ and $98.03 \%$ for COI) and in the genus Scaptotrigona (96.82 and $94.57 \%$ for $16 \mathrm{~S}$ and COI, respectively). These data confirm the success of species discrimination by both regions of the mitochondrial DNA, supporting the efficiency of the PCR-SSCP technique, given its low cost and high accuracy.

Another advantage of PCR-SSCP is its ability to detect even single-base polymorphisms in DNA fragments of a given size (Oohara, 1997). Furthermore, it is possible to analyze degraded DNA and small fragments (Rehbein et al., 1999). This technique may also be used for preliminary screening before sequencing, as completed by several authors in the molecular identification of species (Hodgkinson et al., 2002; MacGregor and Amann, 2006; Mohr and Tebbe, 2006). Such screening is possible because the haplotypes found by PCR-SSCP are confirmed by DNA sequencing, as shown by Barroso et al. (1999).

Thus, we suggest that PCR-SSCP markers are of use for the identification of stingless bee species, in addition being useful for screening for their characterization, based on interspecific haplotypic polymorphisms in the 16S and COI regions of mitochondrial DNA. Such markers could support the taxonomic revision of the tribe Meliponini and, consequently, of species in Apidae. This revision would lead to a reduction in the amount of samples requiring analysis, as well as a reduction in the costs of sequencing.

\section{ACKNOWLEDGMENTS}

We thank Financiadora de Estudos e Projetos (FINEP), Fundação de Amparo à Pesquisa do Estado do Amazonas (FAPEAM), and Conselho Nacional de Desenvolvimento Científico e Tecnológico (CNPq) for financial support.

\section{REFERENCES}

Barroso A, Dunner S and Canon J (1999). Technical note: use of PCR-single-strand conformation polymorphism analysis for detection of bovine $\beta$-casein variants $\mathrm{A}^{1}, \mathrm{~A}^{2}, \mathrm{~A}^{3}$, and B. J. Anim. Sci. 77: 2629-2632.

Bastos E, Cravador A, Azevedo J and Guedes-Pinto H (2001). Single strand conformation polymorphism (SSCP) detection in six genes in Portuguese indigenous sheep breed "Churra da Terra Quente". Biotechnol. Agron. Soc. Environment. 5: 7-15.

Bezerra JMD (1999). Caracterização Morfogenética de Populações de Melipona compressipes fasciculata Smith (Hymenoptera, Apidae) em Diferentes Ecossistemas do Estado do Maranhão (Brasil). Doctoral thesis, Faculdade de Medicina de Ribeirão Preto, Ribeirão Preto.

Brown MJF and Paxton RJ (2009). The conservation of bees: a global perspective. Apidologie 40: 410-416.

Camargo JMF and Pedro SRM (2003). Meliponini neotropicais: O gênero Partamona Schwarz, 1939 (Hymenoptera, Apidae, Apinae) - bionomia e biogeografia. Rev. Bras. Entomol. 47: 311-372. 
Carvalho-Zilse GA and Nunes-Silva CG (2012). Threats to the Stingless Bees in the Brazilian Amazon: How to Deal With Scarce Biological Data and an Increasing Rate of Destruction. In: Bees: Biology, Threats and Colonies (Florio RM, ed.). Nova Science Publishers, New York, 147-168.

Choa U, Takahashi H, Kimura B and Kuda T (2011). Comparison of PCR-DGGE and PCR-SSCP analysis for microflora of Kaburazushi and Daikonzushi, traditional fermented foods made from fish and vegetables. J. Food Technol. 9: 1-8.

Creste S, Tulmann-Neto A and Figueira A (2001). Detection of single sequence repeat polymorphism in denaturing polyacrylamide sequencing gels by silver straining. Plant Mol. Biol. Rep. 19: 1-8.

Cruz DO and Campos LAO (2009). Polinização por abelhas em cultivos protegidos. Rev. Bras. Agrociência 15: 5-10.

Hayashi K (1991). PCR-SSCP: a simple and sensitive method for detection of mutations in the genomic DNA. PCR Methods Appl. 1: 34-38.

Hillis DM, Mortiz C and Mable BK (1996). Molecular Systematics. 2nd edn. Sinauer Associates, Sunderland.

Hodgkinson VH, Birungi J, Haghpanah M, Joshi S, et al. (2002). Rapid identification of mitochondrial cytochrome B haplotypes by single strand conformation polymorphism in Lutzomyia longipalpis (Diptera: Psychodidae) populations. J. Med. Entomol. 39: 689-694.

Lamarão FRM, Reis EC, Simão TA, Albano RM, et al. (2010). Aplysina (Porifera: Demospongiae) species identification through SSCP-ITS patterns. J. Mar. Biol. Assoc. UK 90: 845-850.

MacGregor BJ and Amann R (2006). Single-stranded conformational polymorphism for separation of mixed rRNAS (rRNA-SSCP): a new method for profiling microbial communities. Syst. Appl. Microbiol. 29: 661-670.

Michener CD (2007). The Bees of the World. 2nd edn. The Johns Hopkins University Press, Baltimore.

Miller M (1997). Tools for Population Genetic Analyses (TFPGA). Version 1.3. Northern Arizona University, Flagstaff.

Mohr KI and Tebbe CC (2006). Diversity and phylotype consistency of bacteria in the guts of three bee species (Apoidea) at an oilseed rape field. Environ. Microbiol. 8: 258-272.

Moure JS, Urban D and Melo GAR (2007). Catalogue of Bees (Hymenoptera, Apoidea) in the Neotropical Region. Sociedade Brasileira de Entomologia, Curitiba.

Nei M (1978). Estimation of average heterozygosity and genetic distance from a small number of individuals. Genetics 89: 583-590.

Nogueira-Neto P (1997). Vida e Criação de Abelhas Indígenas sem Ferrão. Editora Nogueirapis, São Paulo.

Oohara I (1997). Detection of single strand conformation polymorphisms (SSCPs) on mitochondrial DNA fragments between two domesticated strains of rainbow trout Oncorhynchus mykiss. Fisher. Sci. 63: 151-152.

Paxton RJ, Thoren PA, Tengo J, Estoup A, et al. (1996). Mating structure and nestmate relatedness in a communal bee, Andrena jacobi (Hymenoptera, Andrenidae), using microsatellites. Mol. Ecol. 5: 511-519.

Rehbein H, Mackie IM, Pryde S, Gonzales-Sotelo C, et al. (1999). Fish species identification in canned tuna by PCRSSCP: validation by a collaborative study and investigation of intra-species variability of the DNA-patterns. Food Chem. 64: 263-268.

Roubik DW (1989). Ecology and natural history of tropical bees. Cambridge University Press, Cambridge.

Schwieger F and Tebbe CC (1998). A new approach to utilize PCR-single-strand-conformation polymorphism for $16 \mathrm{~S}$ rRNA gene-based microbial community analysis. Appl. Environ. Microbiol. 64: 4870-4876.

Sheffield CS, Hebert PD, Kevan PG and Packer L (2009). DNA barcoding a regional bee (Hymenoptera: Apoidea) fauna and its potential for ecological studies. Mol. Ecol. Resour. 9 (Suppl s1): 196-207.

Silveira FA, Melo GAR and Almeida EAB (2002). Abelhas Brasileiras: Sistemática e Identificação. Fundação Araucária, Belo Horizonte.

Simon C, Frati F, Beckenbach A, Crespi B, et al. (1994). Evolution, weighting, and phylogenetic utility of mitochondrial gene sequences and a compilation of conserved polymerase chain reaction primers. Ann. Entomol. Soc. Am. 87: 651-701.

Slaa EJ, Sánchez Chaves LA, Malagodi-Braga KS and Hofstede FE (2006). Stingless bees in applied pollination: practice and perspectives. Apidologie 37: 293-315.

Sousa CS, Kerr WE, Bonetti AM, Souza CS, et al. (2003). Comparação das técnicas de SSCP, DS-PCR, PCR-RFLP para detecção de mutação no gene mitocondrial 16S rRNA em populações de Melipona rufiventris. Bioscience J. 19: 65-70.

Sriphairoj K, Klinbu-nga S, Kamonrat W and Na-Nakorn U (2010). Species identification of four economically important Pangasiid catfishes and closely related species using SSCP markers. Aquaculture 308: S47-S50.

Vences M, Thomas M, van der Meijden A, Chiari Y, et al. (2005). Comparative performance of the 16S rRNA gene in DNA barcoding of amphibians. Front Zool. 2: 5. 